\title{
METODER FOR EN FLERARTSANTROPOLOGI
}

At tænke med laks, otolitter og fiskeskæl

\section{HEATHER ANNE SWANSON}

„Sådan ser jeg laks," sagde George og rakte mig et lille stykke hvidt forkalket stof (se figur 1). Som det lå der i folderne i min håndflade, lignede det en knækket muslingeskal. Det var en otolit, eller hvad der også beskrives som „øresten“. George - en erfaren fiskeriforsker og leder ved et universitet i Californien - tilbringer meget af sin tid med at arbejde med sådanne benede chips: med at få dem til at fortælle historier. Han monterer dem på plader og polerer dem så tynde, at deres trælignende ringe kan tælles, måles og analyseres i bestræbelsen på at lære laksenes livshistorier at kende. George arbejder næsten aldrig med levende laks, men i stedet med otolitter, som ankommer i små hætteglas, hvor de allerede er adskilt fra laksens krop. Når George siger, at han „ser“ laks sådan, er det således ikke gennem fiskeri eller madlavning eller for den sags skyld gennem feltarbejde: Han ser dem praktisk talt gennem et mikroskop, hvilket er nødvendigt for at „aflæse“ de mikroskopiske markeringer på otolittens overflade.

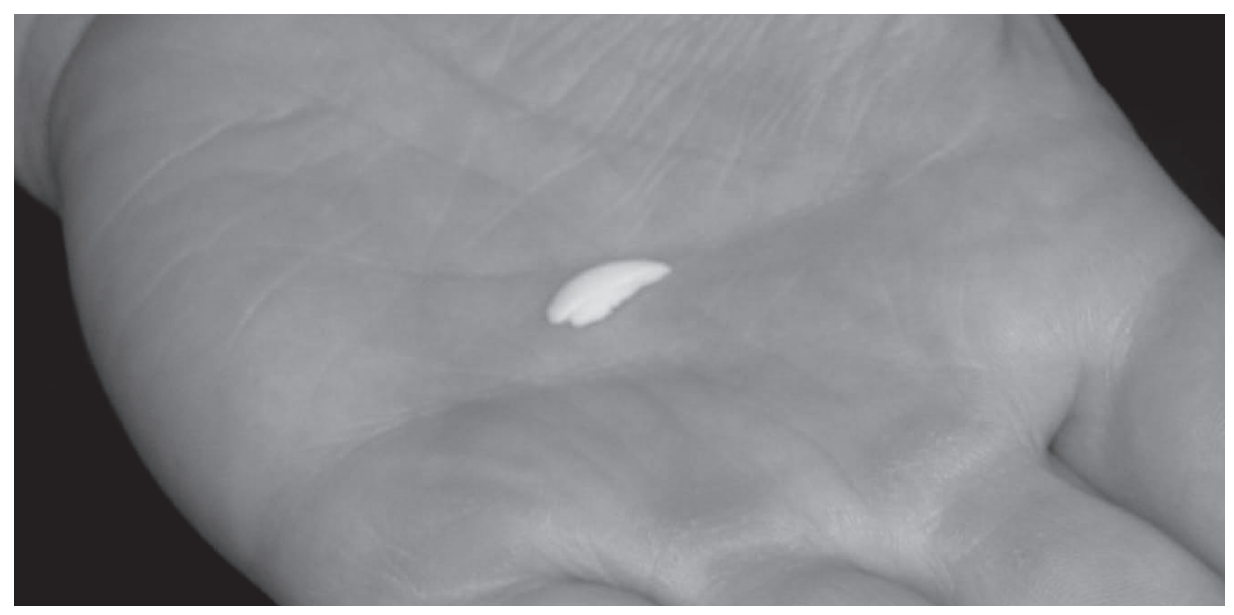

Figur 1. En otolit (øresten) hviler i Georges håndflade. (Foto: Heather Anne Swanson). 
Jeg indleder med denne korte beskrivelse af George, fordi den er en del af en allerede velkendt genre. De måder, hvorpå laks ,konstitueres“ i laboratoriepraksisser, er netop dét, som optager forskere, der beskæftiger sig med flerartsantropologi og videnskab- og teknologistudier (STS), noget, de efterhånden er blevet dygtige til at studere. Forskere uddannet i samfundsvidenskab og humaniora er løbende blevet kompetente til at spørge kritisk til, hvordan forskellige mennesker undersøger, forstår og gør andre arter; både dyr, planter og landskaber. ${ }^{1}$ Denne artikel starter dog et andet sted. Den begynder netop ikke med nysgerrighed på menneskelige videnspraksisser, men ved nysgerrighed på fisk - og især de laks, som også har fanget Georges opmærksomhed.

Antropologerne Jensen og Morita henleder vores opmærksomhed på det, de kalder „,de mindre antropologier“, det vil sige antropologier med „,konceptuelle og beskrivende stilarter, der distingverer dem fra de store traditioner, men som ellers ikke er radikalt adskilt fra eller uforlignelige med dem“ (Jensen \& Morita 2017:4). Med henvisning til antropologerne Marilyn Strathern og Eduardo Viveros de Castro som eksempler på antropologer, der bruger deres etnografiske materiale til at udfordre/ disrupte vestlig antropologisk ,theory-as-usual“, foreslår Jensen og Morita, at netop den slags videnskabeligt arbejde presser os til at forestille os „former for antropologi, der ikke blot [tager] menneskers praksis og kosmologiske opfattelser som etnografiske data, som kan analyseres ved brug af antropologiens standardteorier, men som konceptuelle udgangspunkter for at udvide, omdefinere eller udfordre dem“ (Jensen \& Morita 2017:2). Jeg argumenterer for, at som vi kan udforske sådanne mindre antropologier gennem forskellige folks kosmologier, er det ligeledes muligt at forestille sig nye former for antropologi gennem ikke-menneskelige praksisser. ${ }^{2}$

I det følgende sigter jeg således efter at lade min egen nysgerrighed om laks mønstre nye refleksioner om de udfordringer og muligheder, der opstår inden for det antropologiske forskningsfelt, vi kalder flerartsantropologi. Hvad sker der, når antropologer stiller nye spørgsmål - med udgangspunkt i ikke-mennesker og ikke-menneskelige ,assemblages“ - i et felt, der har en lang tradition for at tage udgangspunkt i mennesker? Der vil utvivlsomt opstå en række spørgsmål om metoder, og de metodiske udfordringer heri er utvivlsomt centrale, da antropologien ofte definerer sig netop gennem sine etnografiske metoder. Afsættet for en ,ikke-humanistisk“ antropologi kræver dog en forskningspraksis, der udfordrer konventionelle metodologiske forventninger. I det lys koncentrerer denne artikel sig også om nogle af de ,små metoder“, der opstår i dette spændingsfelt, og adresserer, hvordan vi kan sætte os i stand til at genoverveje nogle af antropologiens metodologiske antagelser - herunder disciplinens orientering mod naturvidenskaben. 


\section{Flerartsantropologi: nye nysgerrigheder}

Flerartsantropologi er på mange måder et resultat af, hvad man kan kalde en ringe disciplineret nysgerrighed. Antropologer, som tidligere undersøgte klassiske kulturelle emner - såsom naturvidenskabelige måder at skabe viden på, politisk økologi, oprindelige folks måder at forvalte naturen på - er blevet mere intellektuelt promiskuøse og tillader sig derfor i stigende grad at rette deres nysgerrighed ikke alene mod menneskelig praksis, men også mod den såkaldte natur (Kirksey \& Helmreich 2010; Tsing 2014). Naturvidenskabelige forskere, som senere er konverteret til samfundsvidenskaberne, har hjulpet med at vise de iboende potentialer af sådanne tværfaglige reorienteringer og bestræbelser. Filosof og fysiker Karen Barad (2007) har eksempelvis demonstreret, hvordan dobbeltslids-eksperimentet udgør en åbning for nye forståelser af ontologi, politik og etik. Og biolog og STS-forsker Donna Haraway (2008) har gennem sin fascination af symbioser - som den mellem den hawaiiske bobtailblæksprutte og vibriobakterier - udviklet nye begreber om relationalitet, der udfordrer dominerende diskurser om individualisme. Begge illustrerer, at en skærpet opmærksomhed på verdens ikke-menneskelige materialitet kan gøre en stor forskel på, hvordan man udvikler teori inden for samfundsvidenskab og humaniora. Deres arbejde tillader os at lede efter store og transformative spørgsmål på eksisterende videnskabelige formationers randzoner.

Promiskuøse flerartsnysgerrigheder udfordrer på flere måder forudsætningerne for tidens antropologi og forårsager således også en slags disciplinær rådvildhed (Viveiros de Castro 2004). I løbet af de seneste 150 år er antallet af polyhistorer svundet ind. Muligheden for at være interesseret i iroquoisslægtskab $o g$ bæveres dæmningsbyggeri - begge emner, som optog antropologen Lewis Henry Morgan - er i dag forsvundet i tiltagende specialisering. Og i de senere år er genstandene for antropologernes undersøgelser blevet stærkt betinget af fortsat mere rigide disciplinære grænser, som også delvist er knyttet til sondringen mellem kategorierne natur og kultur. Højt specialiserede naturvidenskabsforskere skulle undersøge og rapportere om verden, hed det sig, mens samfundsvidenskaberne og humaniora beskæftigede sig med fortolkninger af og diskurser om verden. Men i en tid med ekspanderende miljøkriser har nogle antropologer fundet sådanne sondringer og tilgange utilstrækkelige, særligt i forhold til at finde ud af, hvordan vi kan sameksistere med andre væsener. Måske, spørger de, skal vi vide mere om andre væseners livsverdener, og hvordan mennesker deltager i disse verdener? Flerartsantropologer har derfor valgt en materialistisk og empirisk tilgang til dette kompleks og spurgt, hvordan mennesker og ikke-mennesker sammen deltager $i$ at skabe nye fælles verdener. 
Flerartsantropologi markerer sig således ved på betydelig vis at omdefinere antropologiens undersøgelsesobjekt. Flerartsetnografer insisterer på, at man for at forstå sociale verdener også må betragte ikke-menneskelige socialiteter, som antropologien med dens ofte snævre definitioner af det „menneskelige“ og det „sociale“ har forsømt (Kirksey \& Helmreich 2010; Tsing 2014). Anna Tsing (2012:144) hævder således, at også antropologer er blevet fanget i pandisciplinære projekter, hvori man ,forestiller sig, at menneskearten, det vil sige praksissen at opretholde sig som art, er autonomt selv-opretholdende“". Tsing (2014), blandt andre, udfordrer denne begrænsede definition af antropos (mennesket) ved at insistere på, at man for at forstå betydningen af ,at være menneske“ på samme tid også må udvide det antropologiske blik til at omfatte mere-end-menneskelige relationer. ${ }^{3}$ Flerartsforskere har derfor også opfordret andre samfundsvidenskabelige forskere til at fokusere på ikke-mennesker i håb om at undgå at reproducere den slags faglige nærsynethed, der fortsat strukturerer en stor del af den akademiske verden. Nærmere bestemt beder de os om ikke kun at være nysgerrige på, hvad folk som George gør ved og siger om laks, men også på selve laksens liv.

Flerartsantropologi bliver således også et svært forviklet felt sammensat af flere forskellige discipliner, hvor en artikulation af væsener såsom laks, der typisk betragtes og italesættes som et biologisk studieobjekt, også må gøres genkendelig i et samfundsvidenskabeligt sprog. På sin vis er denne artikulation allerede godt i gang, som det også fremgår af den voksende mængde af flerartsforskning. Metodisk er meget dog fortsat u- eller underudforsket. Og mens flerartsantropologi har fremsat stærke påstande om vigtigheden af at være nysgerrig over for ikke-menneskelige aktører, har feltet endnu ikke på tilstrækkelig vis behandlet de iboende metodologiske dilemmaer, som denne nysgerrighed afstedkommer. Hvordan studerer man rent faktisk ikke-mennesker inden for en disciplin, hvis metoder er overvejende menneskeorienterede? Hvilke metodiske forskydninger kan vi få brug for?

\section{Metoder, praksisser og instrumenter}

For at beskrive nogle mulige fremgangsmåder for flerartsantropologi vil jeg trække på min egen forskning om stillehavslaks, samt analyser af lakseskæl og otolitter. Jeg vil bruge disse detaljer om laks til at argumentere for, at de nysgerrigheder, som flerartsantropologi søger at dyrke, kræver særlige observationsmetoder, der strækker grænserne for, hvad vi typisk tænker på som „etnografi“. Laksens socialiteter (både til og hinsides mennesker) kræver, at antropologer lærer at „aflæse“ laksekroppe. Til dette formål foreslår jeg, at vi gør os bekendt 
med nogle af de fremgangsmåder og instrumenter, som folk som George bruger til at skabe ny viden om andre arters verdener.

Tag de stillehavslaksarter, som er genstand for Georges forskning. Når laks migrerer fra flod til hav og tilbage igen, konstituerer disse peripatetiske fisk deres omgivelser på flere måder: De følger særlige strømme og sporer dermed komplekse migrationsruter, hvorefter de vender tilbage til de floder, de kom fra. Under gydning bygger de rede med deres haler, hvilket ændrer flodens morfologi, og når de dør, frigiver deres rådnende fiskekroppe det fosfor og kvælstof, som de optog fra havvand, ud i ferskvandsstrømmene, hvilket forandrer cirkulationen af næringsstoffer på tværs af vandskel.

De måder, hvorpå laks konstituerer landskaber og vandskaber, forandrer også menneskers liv og historier på afgørende vis. Tænk eksempelvis på, hvordan folk i oprindelige samfund har struktureret deres levevis efter laksens migration- og bevægelsesmønstre. Eller overvej, hvordan laks former industrisamfund: Laksens migrationsmønstre påvirker både, hvordan vandkraftanlæg er blevet designet, og den mængde strøm, de genererer. Yderligere har laksens behov for kølige strømme også ført til dannelsen af nye tømmerpolitikker, der blandt andet skal sikre trædække ved flodbredder, samt nye regulativer for ranching, der forhindrer kvæg $i$ at nedtrampe strømbede og flodbredder og endda nye regler for landbruget, der reducerer næringsstoftilførsel. Kort sagt er de fleste arealanvendelsespraksisser i lakses nærhed i tæt dialog med fisken.

Men hvordan studerer man som antropolog så egentlig laks? Trods entusiasmen har flerartsantropologien vist sig udfordrende, blandt andet fordi den afslører nogle af etnografiens iboende sårbarheder. Det er således relativt let at påpege, at vi bør tage ikke-mennesker mere alvorligt, men det er på samme tid svært at vide, hvilke videnspraksisser vi skal benytte i forhold til at undersøge ikke-menneskelige praksisser. De klassiske samfundsvidenskabelige værktøjer, der normalt giver os gode betingelser for at studere en eller anden form for praksis - eksempelvis de handlinger og praksisser hvorigennem forskere, fiskere og oprindelige folk forstår og gør fisk - synes til gengæld utilstrækkelige i forhold til at studere ikke-mennesker. Og det samme gør sig gældende for de tilgange, vi kender fra aktør-netværksteori (ANT) og STS-forskningen. Her er det eksempelvis vigtigt, bemærker antropologen Bruno Latour (2004), at tale med ,repræsentanten“ (dvs. forskeren, fiskeren) for de ikke-mennesker, man ønsker at studere. Men dette er ikke altid tilstrækkeligt. Hvad gør vi, hvis vores nysgerrighed, eller vores spørgsmål vedrørende ikke-mennesker adskiller sig fra de spørgsmål, som stilles af deres repræsentant - en biolog eller måske en zoolog? De STS-inspirerede tilgange, der fremføres af antropologer som Annemarie Mol og John Law, og som undersøger, hvordan ting konstitueres i praksis, har vist sig at være 
yderst velegnede til at analysere livligheden ved sygdomme og teknologiske apparater. Denne tilgang har imidlertid også sine utilstrækkeligheder i forhold til at studere levende væsener, som ikke alene „konstitueres“ gennem menneskelig praksis, men som også selv er i stand til at „,konstituere“ deres omgivelser. ${ }^{4}$ Mens vi spørger, hvordan George konstituerer laks, kan vi ligeledes søge at begribe, hvordan laks konstituerer verden?

Dette spørgsmål er naturligvis omgærdet af usikkerheder og risici - både i ontologisk, politisk og disciplinær forstand. Men dette er sårbarheder, som jeg mener, vi bør omfavne. Hvis vi skal spørge, hvordan laks forstår landskaber, har vi måske brug for at formulere nye erkendelsesmåder som tilføjelse til konventionelle socialvidenskabelige metoder. Dette skridt betyder naturligvis ikke, at vi skal forkaste allerede eksisterende samfundsvidenskabelige værktøjer til kulturel og politisk analyse, men snarere at vi bør omfavne og tage ansvar for den opgave, der ligger $i$ at skabe en disciplin, der reflekterer over sine egne metoder, historier og praksisser - herunder dens arv fra den menneskelige exceptionalisme.

\section{Etnografiske eksperimenter}

I et forsøg på at udvide den etnografiske værktøjskasse har flerartsantropologer trukket på en stribe andre discipliner og felter. Et af de områder, hvor de almindeligvis har draget inspiration, har været biologiens adfærdsforskning. Andre antropologer har vendt sig mod etologien eller dyretrænere (Allen og Bekoff 1997; Hearne 1987; Smuts 2001) for at lære at spore sig ind på og fortolke ikkemenneskelige adfærdsmønstre og handlinger (Despret 2004; Haraway 2008). Men når antropologer nu har orienteret sig mod disse felter, har de ofte også haft en tendens til at henvende sig til forskere, hvis forskning er epistemologisk kompatibel med deres egen. Eksempelvis har nogle af disse antropologer indgået særdeles frugtbare samarbejder med primatologer - både metodisk og teoretisk - hvor komplekse begreber som „kultur“, ,tradition“ og ,,personlighed“ allerede er i spil. ${ }^{5}$

Alligevel, mens flerartsantropologer har været yderst produktive i deres studier af blandt andet dyreadfærd, har de dog også produceret nogle betydningsfulde faglige lakuner. Eksempelvis har dyreadfærdsforskere i overvældende grad studeret pattedyr, og flerartsforskere har haft tendens til at gøre det samme. Der findes derfor også en stor mængde forskning om pattedyr - ikke-menneskelige primater, kæledyr og husdyr - hvilket må siges at være et ret smalt udsnit af det samlede flerartslige liv, vi finder på kloden. ${ }^{6}$ Dette fokus er imidlertid dikteret af metoden: De eksisterende metoder man finder fra dyreadfærdsforskning, som typisk baserer sig på observationer af dyrs kropssprog og af deres sociale forhold, 
fænomener, der er umiddelbart synlige for det menneskelige blik, er simpelthen bedre egnet til at studere pattedyr (og fugle) end andre livsformer. Med andre ord er disse observationsmetoder, som baserer sig på umiddelbar menneskelig observans bedre egnet til, eksempelvis, at studere hunde end bakterier.

Antropologer, der arbejder med insekter, planter og svampe, har ofte samlet indsigt fra naturhistorien og beskrivende biologi (Raffles 2010). Inspireret af naturforskernes mange omhyggelige bemærkninger og notater (Canfield 2011; Herman 1980), som i mange tilfælde minder om klassiske antropologiske beskrivelser og tekster (fx Evans-Pritchard 1940; Malinowski 1935; Rappaport 1968), konstruerer de særlige former for empirisk observation, der omfatter sociale verdener hinsides den menneskelige. Ét eksempel på dette finder man hos Anna Tsing (2014), som i sit arbejde i de skove, hvor matsutakesvampene gror, har opfordret antropologer til at engagere sig i den tværfaglige iagttagelsespraksis, hun kalder „,kritisk beskrivelse“. Tsing understreger vigtigheden af at notere sig så forskellige ting som kapitalistisk praksis, skovsuccession og svampevækst for bedre at forstå, hvordan igangværende sociale historier udfolder sig i de landskaber, vi undersøger.

De tilgange, der har rod i den naturhistoriske tradition, har dog også sine begrænsninger. Selv om sammenviklingen af etnografiens og naturhistoriens metoder har bragt menneskers og dyrs historier ind i den samme analytiske ramme, har man fastholdt fokusset fra begge tilgange på direkte observationer af en observatør i kød og blod, og typisk fra noget, der minder om det blotte øje (Haraway 1988). At udvide etnografi gennem naturhistoriske observationer hjælper os dog ikke metodologisk med at begribe og håndtere de ting, som vi ikke kan se direkte og personligt.

Og dette er et enormt problem, hvis man vil studere eksempelvis mikrober, havstrømme, langsigtede evolutionære processer eller, som i mit tilfælde, laks.

Ydermere omgår dette stærke fokus på feltobservationer også nogle af de iboende epistemologiske spørgsmål om at bedrive „videnskab“ som antropolog. Naturhistoriens metoder minder på mange måder om vores velkendte og afholdte „deep hanging out“. Men hvad sker der, hvis vi kigger væk fra den direkte feltobservation og i stedet vender os mod kemiske analyser, der udføres på diverse laboratorier, ikke som „deltagerobservation“, men som en antropologisk praksis i sig selv? Sådanne skift kan vække uro og udfordrer, hvad vi opfatter som vores disciplinære forpligtelser. ${ }^{7}$

Geografer, hvis felter også har forrykket sig med ,den animale vending“, er begyndt at undersøge mulighederne i, hvad man kan kalde „,mixed methods“. I en nyere artikel foreslår Hodgetts og Lorimer (2014), at dyregeografer med interesse $\mathrm{i}$ at udforske artshistorier måske er bedre tjent med at benytte følgende tre 
metoder: 1) tekniske anordninger til sporing og dataindsamling af dyr eller arter, som ellers er svære at følge, 2) teknologi til at indfange og undersøge de kommunikationsmåder, der falder uden for menneskets typiske visuelle og auditive sanselighed, ${ }^{8}$ og 3 ) genanalyse, herunder plantegeografi. Inspireret af den slags arbejde afsøger jeg antropologiens muligheder for at forfølge lignende metodologiske eksperimenter - for at strække os selv og blive dus med nogle af de metoder og instrumenter som mennesker som George $\mathrm{i}$ bestræbelsen på at skabe ny viden om andre arters verdener.

\section{Når direkte observation fejler: et studie af laksens liv}

I det følgende vil jeg dykke ned i mine egne studier af stillehavslaks, som jeg har udført i Japan og det vestlige USA. Her har jeg fokuseret på, hvordan laks former måder at leve på for en mængde forskellige arter, og hvordan de deltager $i$ en iterativ skabelse og genskabelse af land- og vandskaber i samspil med andre væsener og kræfter. Disse studier kræver selvsagt, at jeg ved noget om, hvordan fiskeri, indfødte levemåder og dæmningskonstruktioner både påvirker og påvirkes af laksens liv. Men det kræver også, at jeg ved noget om laksens liv i sig selv. De fleste laks i disse regioner begynder deres liv i rugerier. De fødes i plastikbakker, opdrættes i store tanke bygget i rustfrit stål og fodres med en pelleteret kost, mens de vejes og måles regelmæssigt. I disse omgivelser er laks åbenlyst synlige for det blotte øje, hvorfor de traditionelle former for etnografisk observation er ret velegnede. Ved at bemærke og nøje beskrive de måder, hvorpå laks reagerer på deres tilværelser i rugerier, kan vi lære meget om deres adfærd og deres forhold til deres verden - en meget menneskeskabt en af slagsen. Men når juvenile laks er blot få måneder gamle, frigives de fra rugeriet ud i det „vilde“. Herefter migrerer de hurtigt til havet, hvor de opholder sig i flere år, og først mange år senere vender de tilbage til den region, hvor de blev født.

Når laks først svømmer fra rugeriet, fordufter mulighederne for direkte observation af deres videre liv. At udføre etnografiske observationer, vel og mærke forankret $i$ og hentet fra direkte observation og deltagelse, er fra laksens frigivelse nærmest umulig. Og det er i situationer som disse, at antropologen begynder at miste sit epistemologiske greb om sagen, og hvor vi får brug for nye værktøjer til at udvide vores observationsmuligheder.

Denne udfordring er dog ikke uden sidestykke i mere menneskecentreret etnografi. Når vi studerer mennesker, vil vi også ofte gerne undersøge praksisser og begivenheder, som vi ikke direkte kan bevidne. Dette er en af grundene til, at vi gennemfører interviews, registrerer livshistorier og foretager arkivstudier: Der er historier, som vi ved er afgørende for vores arbejde, også selv om vi ikke direkte 
kan opleve dem. Af samme årsag bruger vi derfor også ofte diverse teknologier og infrastrukturer såsom biblioteker og museer til at opspore det, vi ikke kan se eller opleve på nært hold. Og uden tøven gransker antropologen arkivet eller taler med ældre informanter om fortiden. Eksempelvis benyttede jeg i mit eget arbejde i Japan mikrofichelæsere (mikroform) til at arbejde mig gennem gamle avisudklip med information om tidligere praksisser inden for fiskeriforvaltning.

Jeg vil nu gøre brug af et særligt kunstgreb - et, der adresserer de centrale spørgsmål i denne artikel. Jeg vil bruge den samme mikroficheenhed, som jeg satte min lid til i Japan, men skifte de gamle avisudklip ud med lakseskæl. Dette er dog ikke blot en hypotetisk udskiftning: En microfichelæser er en ganske almindelig teknologi, som benyttes til at visualisere og forstørre fiskeskæl. Og med lidt kyndig assistance - langt mindre hjælp end det, der kræves for at tillade mig at fortolke dokumenter skrevet på japansk - kan jeg med microfichelæseren lære en masse om laksens liv, som foregår hinsides direkte observation. Lakseskæl er som årringe i træer: I takt med at laksen vokser, udvikler dens skæl koncentriske markeringer (se figur 2).

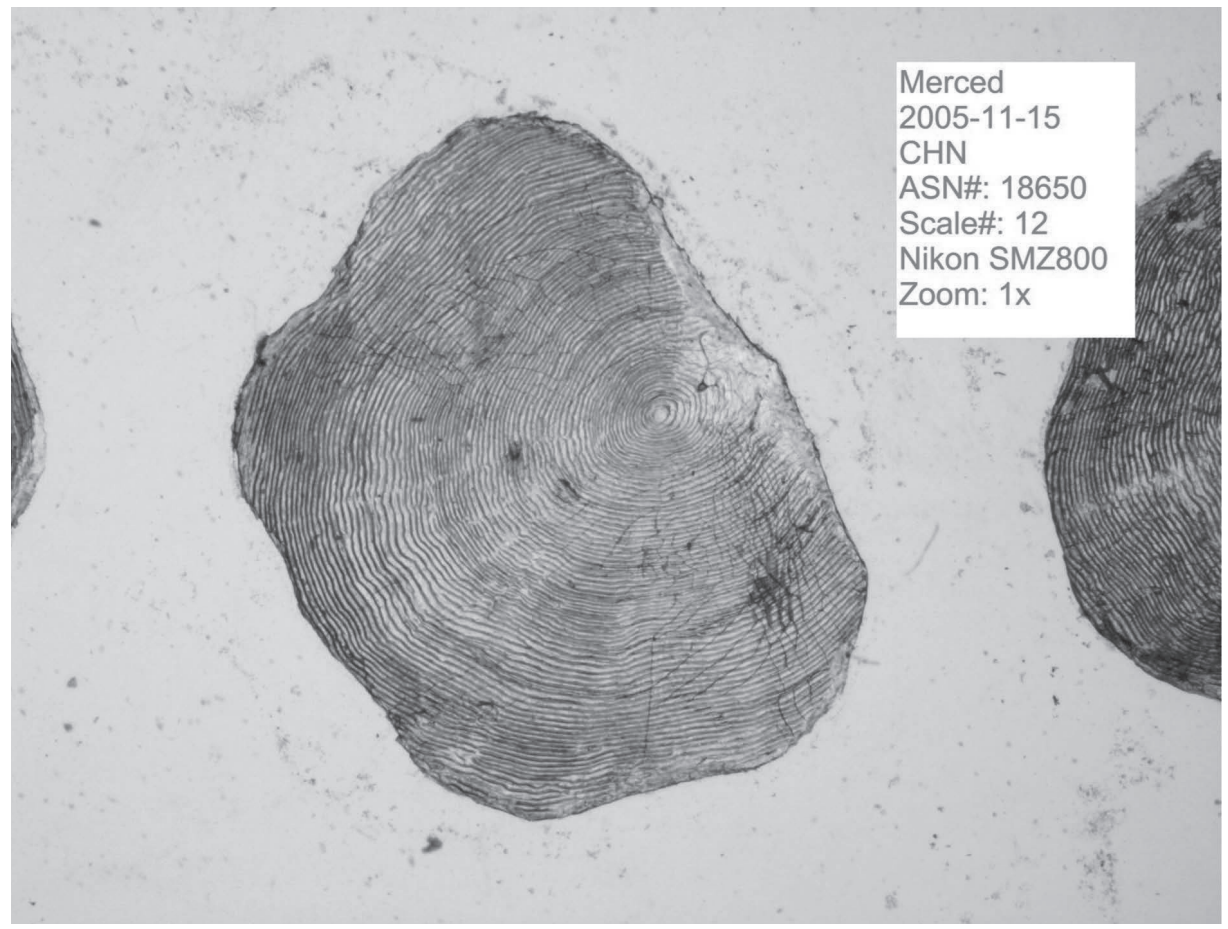

Figur 2. Set under forstørrelse ligner båndmønstre i fiskeskæl træernes vækstringe. Et trænet øje kan i dette billede uddrage information om fiskens alder, dens vækstrate og dens migrationsmønster. (Foto: @California Department of Fish and Game). 
Disse markeringer, som vist i figur 2, fortæller os noget om laksens livshistorie, om de relationer, der skabes, og de tidsligheder, den indgår i. Og bredden på de koncentriske bånd kan fortælle os noget om mønstrene i laksens vækst: hvornår der har været rigeligt med føde, hvornår den har kæmpet for at finde tilstrækkelig næring. Fordi laksen vokser langsommere om vinteren, aflejrer sæsonændringer sig også i de koncentriske markeringer, hvilket yderligere fortæller os noget om laksens alder. Andre linjer på skællene angiver, hvornår laksen overgik fra ferskvand til saltvand, hvilket siger noget om, hvor længe den har levet i forskellige habitater, og hvordan den voksede hvor og hvornår. Ved at „aflæse“ dette laksens ,arkiv“ er vi i stand til at lære mere om de måder, hvorpå laks ser og gør landskaber - noget, der ikke er umiddelbart tilgængeligt gennem almindelige observationsmetoder.

Antropologen Tim Ingold har noteret sig, at ,enhver ting - set på et bestemt sted og i en bestemt tid - indeholder en historie om de forhold, der har bragt den der" (Ingold 2011:160, min oversættelse). Den fænomenologiske idé - at organismer indeholder deres relationshistorier i deres kropslige forfatning - skal i tilfældet af fisk tages ganske bogstaveligt. Selv om de ikke omslutter alle deres historier og alle deres relationer, bærer skæl alligevel en vigtig historie om fisk. Hvis livshistorier - et velkendt og centrals studieobjekt i antropologien - materialiserer sig i laksekroppe, er vi nødt til at lære at se dem - inklusive deres mange markeringer, artikulationer og lagdelte kompleksiteter - for på den måde at få indblik i sociale forhold, som ikke umiddelbart er tilgængelige for etnografien. At forlange dette af os er ikke et outreret forslag. Hvis antropologer kan bruge historiografiens metoder samt diverse teknologier i deres arkivforskning, hvorfor skulle vi da ikke også kunne bruge molekylær- og marinbiologiens metoder og teknologier til at lære mere om laks og laksearkiver?

Stort set alle de antropologer, jeg kender, ender med at udføre en eller anden form for arkivforskning, og det på trods af at meget få af os er ordentligt uddannet i de historiske metoder. Vi er afhængige af vores evne til at lære fra andre discipliner og deres metoder - $\mathrm{i}$ dette tilfælde historie - og integrere dem $\mathrm{i}$ vores egne. Epistemologisk må vi altid huske at forholde os til de udfordringer, som arkiver konfronterer os med, herunder det forhold, at historisk materiale aldrig er neutralt, og at selve dets tilstedeværelse eller fravær er betinget af magtkampe og -forhold. Sommetider fremhæves og behandles disse problemer, men på andre tidspunkter godtages de uden en dybere forklaring af de mange og ofte kontroversielle lag af viden, på hvilke de baserer sig. Men for at fortælle akkurat den historie, som vi ønsker at fortælle, forholder vi os med lige dele skepsis, nysgerrighed, ansvar og åbenhed over for vores historiske materiale. Nogle pointer destabiliseres, mens andre accepteres. Jeg foreslår, at vi tilgår vores engagement med laksens kropsliggjorte historie på samme måde. 


\section{Otolitkollaborationer}

Jeg vil nu henlede opmærksomheden på en anden teknik, med hvilken vi kan observere laks: at kigge nærmere på den lille, forkalkede ting, som vi tidligere $\mathrm{i}$ artiklen så i Georges hånd. Otolitter (også øresten) er små sten i fisks indre øre. Otolitter består af kalciumkarbonat og spormineraler deponeret i en proteinmatrix og har derfor en anden densitet end resten af fiskens ellers porøse krop. Når fisken bevæger sig og dermed oplever vibrationer, støder dens otolitter derfor op mod hårcellerne i det indre øre (mere præcist i cochlea). Denne proces gør, at fisken mærker accelerationer og decelerationer, som hjælper den med at orientere sig (Popper et al. 2005). Men otolitter er ikke kun sanseorganer. De er ligesom fiskeskæl også ting, der afslører en tidsmæssigt sekventeret oversigt over dele af fiskens liv. I forhold til fiskeskæl fortæller otolitter om nogle andre af fiskens relationer i tid og rum. Mens markeringerne i fiskeskæl dannes uregelmæssigt i semiugentlige cyklusser og primært dokumenterer sæsonændringer, knytter markeringerne i otolitterne sig snarere til fiskens daglige rytmer. Der dannes typisk en markering i otolitten om dagen, som så akkumuleres i løbet af hele fiskens liv.

Otolitmarkeringer - skabt gennem fiskens interaktioner med fødekilder, temperaturforhold, saltholdighed, fotoperiode, andre fisk og endda mineraler i nærliggende klippeformationer - kan fortælle os meget om laksens sociale liv. Brede markeringer angiver, at laksen har haft rigelig adgang til mad, befundet sig i moderate temperaturer og været fri fra konkurrence fra andre, mere aggressive fisk. Smalle markeringer angiver derimod dage, hvor fiskens liv har været mere udfordrende. En mørk markering kaldes et „stresstjek“ og repræsenterer en vanskelig livsovergang - en signifikant metabolisk og hormonel stressrespons, som i bogstaveligste forstand efterlader sig et livsvarigt mærke. Eksempelvis vil man hos de unge laks, der opdrættes i rugerier og senere frigives i naturen, typisk se markante tegn på stress i perioden umiddelbart efter frigivelsen. Men kemien i otolitter kan fortælle os endnu mere. De runde huller i otolitten (se figur 3) er spor efter ekstraktion af en mikrokemisk prøve. Isotopiske spor i otolitter kan afsløre noget om mineralsammensætningerne af det vand, hvori laksen har befundet sig på et givent tidspunkt, hvilket giver mulighed for bedre at stykke laksens livsbane sammen. Tilstedeværelsen af visse andre elementer kan også fortælle os, hvornår laksen har ernæret sig ved havafledt protein, og hvornår den har ernæret sig af andre, større hvirvelløse ferskvandsorganismer. Den kemiske sammensætning i markeringerne på otolitten i Georges håndflade viser for eksempel, hvordan laksen først har spist pelleteret rugerifoder af knuste havfisk, siden har ernæret sig ved ferskvandsorganismer i floden for en stund, inden den til sidst er migreret til havet for at genoptage en havbaseret diæt. 


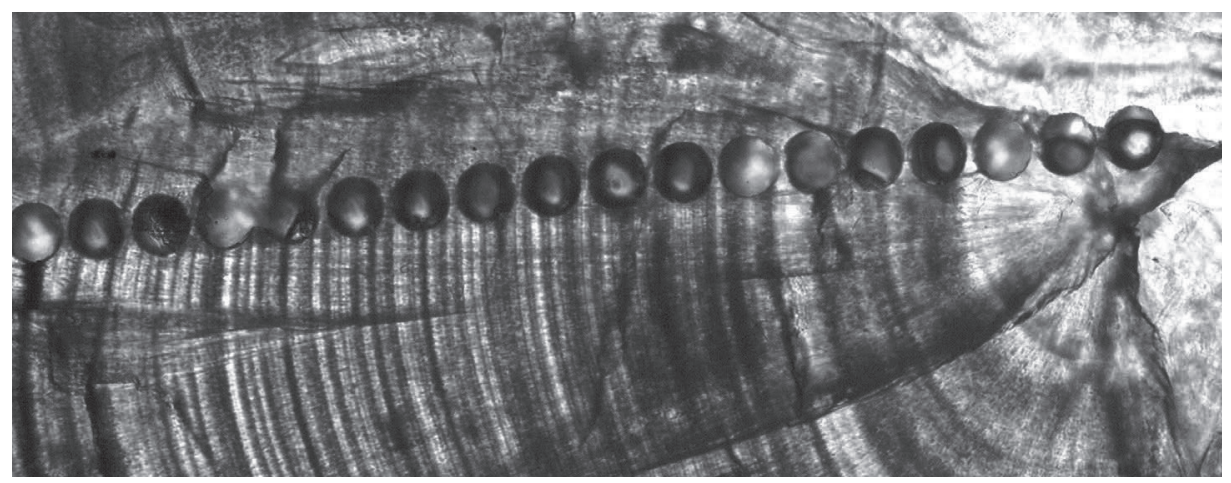

Figur 3. Et otolittværsnit placeret under $100 \mathrm{x}$ forstørrelse. Hullerne indikerer de steder, hvor der er taget prøver til isotopanalyse med et massespektrometer. Hvert hul er 40 mikrometer bredt (1/25 af en millimeter). (Foto: (CRachel Johnson, NOAA Fisheries).

Disse ovenstående eksempler illustrerer blot en brøkdel af de historier, man kan finde i otolittens arkiv. Ved at koble disse markeringer med kemisk analyse kan vi konstruere delvise portrætter af fiskens mangfoldige relationer, idet den navigerer gennem rytmerne af og strømmene i dens akvatiske omgivelser. Sådanne teknikker er uvurderlige i forhold til at lære mere om, hvordan fisk bevæger sig i deres omgivelser og interagerer med andre - og skaber akvatiske verdener - i øjeblikke, hvor vi ikke kan observere dem direkte.

\section{Former for vidensproduktion i mødet mellem arter}

Hvad er det for et billede af laks, som kommer til syne her - og hvordan er det relevant for antropologien og STS? Uden otolitanalyser hælder antropologer til at se laks i en til en-relation med mennesker. Vi fokuserer på de korte øjeblikke, hvor mennesker interagerer direkte med fisk, eksempelvis inden for rugerikultur, når de passerer gennem dæmninger, eller når de bliver viklet ind i et fiskenet, en fælde eller en ruse. Mens disse måder at se og gøre laks på bestemt er vigtige, reducerer de også fisks verdener til øjeblikke med tæt kontakt med mennesker. Analysen af otolitter kan til gengæld hjælpe os med at få proportionerne på plads og til bedre at forstå, hvad mennesker egentlig betyder for laksens liv. Gennem otolitters fortællinger kan vi udsige noget om, hvad mennesker - i rent fysisk forstand - betyder for laks. Vi kan eksempelvis notere os, at laks, efter deres frigivelse fra rugerierne og i deres senere forsøg på at passere gennem dæmningsanlæg, øger deres stressniveau, hvilket giver anledning til metaboliske forandringer, der aflejrer sig i deres knogler. Men vi kan også se, at laksens verden er langt mere end konkrete møder med det menneskeskabte. Otolitter rummer nemlig også historien om, hvordan laks interagerer med mineraler, der udvaskes 
af grundfjeld, byttet, de slider for at fange, prædatorer, de kæmper for at undgå, ruterne, de migrerer ad, årstidernes vekslen og meget andet. Bragt i dialog med etablerede antropologiske former åbner historierne i laksens øresten for langt fyldigere fortællinger, hvor møder mellem mennesker og ikke-mennesker placeres i omfangsrige netværk af flerartslige relationer.

Når George (eller en antropolog) foretager en analyse af en otolit, konstitueres en særlig type eller form for laks. Gennem denne analyse lærer vi imidlertid også noget om laksens konstitueren, praksisser, som inkluderer, men også går hinsides laksens kontaktflade med mennesker. Ved at kigge på og analysere otolitter får vi et glimt af laksens verden, som ganske rigtigt er viklet ind i menneskers verden, men alligevel er forskellig fra den. Jeg behandler her analysen af otolitter som en repræsentant for en lang række videnskabelige praksisser og metoder, der måske kan være i stand til at hjælpe os med at få et bedre metodisk greb om ikkemenneskelige arter i antropologien. I en tid med klimaforandringer, forurening og masseudryddelse er det både praktisk og politisk presserende, at vi forstår, hvordan det at være menneske foregår i en mangfoldighed af flerartslige møder - og vi mangler simpelthen en bedre forståelse af, hvad disse verdener behøver for at overleve.

Netop fordi otolitter indeholder oplysninger om vækstrater blandt fisk, kan de fortælle os noget om de relationelle og flersartslige netværk, i hvilke fisk trives, og i hvilke de ikke gør. Hvis fisk ikke er i stand til at trives og vokse, er deres liv og samfund selvsagt $i$ fare. Ydermere kan mineralindholdet i otolitter også fortælle os om de rejser, fisk foretager, samt hvor stressede de er, når de rejser. Ved at rekonstruere disse rejsemønstre lærer vi mere om de steder, hvor de fisk trives, og de steder, hvor de ikke gør. ${ }^{9}$ På den måde kan otolitter give antydninger om, hvilke slags miljømæssige forstyrrelser der er tålelige for laks, og hvilke der truer selve overlevelsen af deres akvatiske verdener. At se hinsides simple menneske-laks-forhold er essentielt for både at anerkende de afgørende måder, hvorpå visse menneskelige handlinger forstyrrer laksens verdener $o g$ at minde sig selv om, at mennesket ikke er den eneste betydende faktor, selv i det såkaldt antropocæne.

Man behøver dog ikke nødvendigvis at udføre analyser af otolitter eller lignende for at lade naturvidenskabelige metoder berige det samfundsvidenskabelige arbejde om ikke-menneskelige arter. Ofte kan man i al enkelhed også gøre det ved at læse videnskabelige artikler mod hårene, vride dem ind $\mathrm{i}$ andre epistemologiske praksisser. Andre gange er der dog, som det er tilfældet med otolitter, et presserende behov for som antropolog at bebo naturvidenskabelige praksisser. Dette skyldes, at vores spørgsmål til ikke-menneskelige socialiteter ofte er tilstrækkeligt forskellige fra de spørgsmål, man typisk stiller i naturvidenskaben, 
til, at de endnu ikke har undersøgt, hvad vi gerne vil vide. I sådanne tilfælde kan vi finde svar på vores spørgsmål ved at benytte naturvidenskabelige metoder og redskaber, men på nye måder. For mit eget vedkommende rummer analysen af otolitter begge dele. Jeg har lært meget om laksens livshistorier ved at læse publicerede artikler, men den tidligere forskning på området har også sine begrænsninger. For eksempel vil jeg vide, hvad otolitringe fra gydende laks kan fortælle os om deres forhold til deres verden. Jeg har dog fundet meget lidt data om otolittens ydre markeringer - de markeringer, der dannes i de sidste uger af laksens liv - fordi de fleste af de spørgsmål, der i øjeblikket fascinerer forskere, fokuserer på laksens tidlige udviklingsstadier. Derudover er jeg også interesseret $i$ at tegne levende portrætter af individuelle fisk, fra fødsel til død, men om dette emne fandt jeg nærmest ingen forskning, til trods for at det faktisk er muligt at undersøge rent teknisk. For forskere, som har været mest interesseret $i$ at lave statistiske analyser af laksens overlevelsesratio i lyset af forskellige juvenile livsmønstre, har optegnelsen af detaljerede beskrivelser af individuelle fisks hele liv været meget lidt attraktiv. Men disse modeller tegner ikke et levende portræt af laksens liv og verden. De anderledes spørgsmål, som min antropologiske baggrund tilskynder mig at stille - og de forskellige former for viden, som disse spørgsmål kan generere, indikerer, at der inden for samfundsvidenskaberne er gode grunde til at involvere sig i analyser af otolitter og lignende.

\section{Bekymringer om videnskab}

Samfundsvidenskabelige forskere har tendens til at være skeptiske over for de naturvidenskabelige metoder og samarbejder på trods af deres store potentiale i forhold til læring om ikke-menneskelige arter. Er det „ordentlig“ antropologi? Selv med en mængde forbehold bliver de fremgangsmåder, som vi eksempelvis finder i forskningen om otolitter, ofte mistænkeliggjort i antropologien. Jeg er derfor også klar over, at det, jeg foreslår i denne artikel, er risikabelt.

Jeg vil godt understrege, at jeg ikke mener, at naturvidenskaben og dens værktøjer er de eneste måder at lære om laks og deres verdener på. Jeg har for eksempel også lært meget om laks fra fiskere, og jeg betragter ikke deres viden som sekundær. Net og fiskeliner er, ligesom den videnskabelige analyse af otolitter, effektive værktøjer i forhold til at lære mere om laks, især når de er under vand og derfor ude af syne. Når jeg her lægger vægt på naturvidenskabelige metoder, er det, fordi de repræsenterer en form for viden, som antropologer systematisk har holdt sig fra - på bekostning af flerartsforskningen. Vi antropologer ville ikke tøve med at gribe en fiskestang og forsøge at lære noget om laks fra vejrbidte og erfarne fiskere, men vi er tilbageholdende med at engagere forskere og naturvidenskabelige 
metoder i tilsvarende samarbejder. Kort sagt er naturvidenskaben og dens metoder forsat marginaliseret i den moderne antropologi.

Denne marginalisering har vigtige historiske årsager: Antropologer har gennem tiden forsøgt at udgrænse narrativer om den vestlige modernitet og oplysningshumanisme, som videnskab er tæt forbundet med. Jeg vil ikke hævde, at de tilgange, jeg i denne artikel advokerer for, ikke også medfører risici i forhold til det vigtige epistemologiske arbejde, der ligger i at udfordre naturvidenskabens evne til at fremlægge dominerende udlægninger af verden. Jeg vil dog argumentere for, at risiciene ved midt i afgrundsdybe miljømæssige kriser at patruljere de praksisser, med hvilke vi kan lære at forstå flerartslige verdener, er langt større. Faktisk er de naturvidenskabelige metoder så nyttige i forhold til at forstå ikke-mennesker, og det vil være uansvarligt af os at afvise dem uden videre. Men at bruge naturvidenskabelige artikler til at forsyne såkaldt „baggrundsinformation“ for det antropologiske arbejde - en ganske almindelig praksis inden for antropologi - er ikke nok. Flerartsantropologi kræver mere intime forhandlinger med naturvidenskaben.

Spændingerne mellem flerartsantropologi, (natur)videnskab og metode er næsten allestedsnærværende, selv om det sjældent ekspliciteres. En del af spændingerne er knyttet til antropologiens tendens til at opstille kategoriske modsætningsforhold mellem animisme/det traditionelle/autenticitet og naturvidenskab/det moderne/Vesten. Hvor animisme ofte betegnes som berigende og livliggørende for verden - med ontologisk mangfoldighed og nye politiske mulighedsrum, formodes naturvidenskaben at aflive den gennem skabelsen af et singulært positivistisk perspektiv, som afstiver allerede dominerende „moderne“ ontologier. Det er nærmest overflødigt at sige, at de følelser, som dette modsætningsforhold fostrer, skaber dårlige betingelser for at styrke alliancer i en fælles interesse for ikke-mennesker. Sådanne essentialiserende tendenser risikerer snarere at genoplive de såkaldte „,krige mellem videnskaberne“ ${ }^{10}$ end de øger chancerne for nye samarbejder i deres kølvand - samarbejder, der potentielt tilvejebringer nye forskningsmæssige alternativer. Hvis vi vil lære mere om laksens ontologiske praksis, bør vi ganske rigtigt ikke affærdige indfødte metoder, men ej heller naturvidenskabens. Naturvidenskaben behøver ikke nødvendigvis at stå i kontrast til animisme med praksisser, som afliver verden og forarmer politik. ${ }^{11}$ Naturvidenskab kan i sig selv være ,ikke-moderne“ og kan bidrage til at skabe andre verdener. Animistisk videnskab er således ikke en umulig neologisme.

Når jeg afviser det binære modsætningsforhold mellem naturvidenskab og animisme, betyder det ikke, at jeg mener, der findes én ontologisk verden, som er enestående, eller at naturvidenskab er den ene hovedkategori eller centrale videnskab, mod hvilken alle andre videnskabelige praksisser skal måles. I ste- 
det argumenterer jeg for, at vi må spille rollen som ,trickster“ - endnu et antropologisk nøglebegreb - ved at bevæge os mellem verdener, være multiple, og dermed sløre grænserne mellem videnskaberne (Haraway 1988). Og for at foretage en mere fyldig og seriøs undersøgelse af ikke-mennesker, eksempelvis såsom laks, må vi i flerartsantropologien kræve at inkludere naturvidenskabelige metoder snarere end at frastøde dem - det er ikke et spørgsmål om ,enten-eller“, men om „både-og“.

Alle metoder er mangelfulde, og de metodiske redskaber, vi bruger, er de eneste, vi har. Hvis vi begrænser vores metodiske værktøjskasse for meget, og ovenikøbet erklærer, at nogle metoder slet ikke er brugbare, ender vi til sidst også med at begrænse de måder, hvorpå vi kan tilegne os ny viden. At samarbejde med naturvidenskabelige forskere betyder ikke nødvendigvis at opgive sit eget kritiske blik på visse former for viden. Med henvisning til Barbara Smith understreger Jensen og Morita, som jeg henviste til i begyndelsen af denne artikel, at „forskere er i stand til at skabe 'sofistikerede konjunktioner' af viden, hvis de forbliver nøje afstemt og refleksive om forskelligheden af deres brug af begreber og antagelser" (Jensen \& Morita 2017:10).

\section{Epistemologiske og politiske udfordringer}

Feministiske videnskabsstudier giver nogle fingerpeg om, hvordan vi kan imødekomme de epistemologiske og politiske udfordringer. Ved at være særligt opmærksom på de måder, som race, klasse og køn påvirker og giver form til viden på, har de feministiske videnskabsstudier traditionelt været kritiske over for mange videnskabelige epistemologier og praksisser, herunder grundlæggende idéer om videnskabelig objektivitet (Harding 1986; Keller 1982; Longino 1990). Forskere inden for feministiske videnskabsstudier er dog ingenlunde imod naturvidenskab. De indgår i tæt dialog med videnskab og kommer ofte selv fra naturvidenskabelige kredse. I stedet for blankt at afvise naturvidenskab bedriver de videnskab anderledes. Og i deres forpligtelse over for at vide mere om den materielle verden, når dagen er omme, end da den begyndte, har disse forskere vredet værktøjer og prakisser fra fagområder som primatologi (Strum \& Fedigan 2000), biologisk antropologi (Tanner \& Zihlman 1976), fysik (Barad 2007) og biologi (FaustoSterling 1992). Frem for at opgive deres forpligtelse over for empirisme og objektivitet har de understreget den politiske nødvendighed af fortsat at fremsætte realitetsprincipper om virkeligheden. Ved også at understrege uholdbarheden af både klassisk objektivisme, som vi kender det fra naturvidenskaben, og social konstruktivisme, som vi kender det fra samfundsvidenskaben, har de vist os, at blot fordi fakta er ,produceret“, er de ikke pure opspind. I deres forsøg på at skabe 
nye videnskabelige perspektiver hævder de, at videnskab altid er situeret og derfor altid foregår på et bestemt ,sted“, på et bestemt ,tidspunkt". Også videnskab er derfor ,partielle perspektiver“ (Haraway 1988; Harding 1986). Og alt imens de minder os om vidensproduktionens aldrig uskyldige karakter, har feministiske videnskabsstudier også demonstreret, at brugen af naturvidenskabelige værktøjer og teknikker ikke automatisk medfører, at man mister sit kritiske blik - eller sit medlemskab i en kultur, som påstår ikke at have en kultur.

Jeg foreslår således, at vi overfører dette forhold til videnskab til det forhåndenværende materiale. Dermed kan man altså studere laksens sociale verden via otolitter, samtidig med at man bevarer sit kritiske blik på øvrige videnskabelige påstande. Faktisk mener jeg, at det er bydende nødvendigt, at vi gør netop det. Hvad der er særligt interessant ved analysen af otolitter og lignende praksisser for en antropolog som mig, er ikke som sådan, at jeg bliver en naturvidenskabelig forsker, men snarere at mit blik for laksens sociale historie gennem arbejdet med laksens kropslige arkiver får langt større udsigelseskraft og -rækkevide.

Efter udgivelsen af Writing Culture (Clifford og Marcus 1986) er antropologer i høj grad blevet opmærksomme på, hvilke muligheder og begrænsninger der er for, hvad vi egentlig kan vide. Selv om denne nyerhvervede årvågenhed $\mathrm{i}$ nogle henseender har forværret antropologernes skepsis og foragt for objektivitet og naturvidenskab og lejlighedsvist også har ført til overdrevet selvrefleksiv og nærmest solipsistisk prosa, har de fleste antropologer generelt været i stand til at afklare, hvordan vi kan og bør fremstille og skildre andres liv. Og så alligevel: Jo mindre kropslige og jo mindre deltagende antropologer er i de felter, de studerer, jo større ubehag oplever vi typisk. Antropologens idealiserede selvbillede i felten er derfor på mange måder tættere på en naturforsker i felten end en hightechforsker i et laboratorie. Det til trods bør vi alligevel ikke undlade at engagere os i nye metodologiske eksperimenter, som er centrale for flerartsantropologi. For selv om det er klart, når alt kommer til alt, at brugen af teknologi $\mathrm{i}$ vores arbejde så afgjort præger vores observationspraksisser og -betingelser, sker det ofte på uforudsigelige måder.

Teknikker som analyse af otolitter leder nemlig ikke nødvendigvis til at begå den synd, som Donna Haraway (1988) kalder for „gudstricket“ - indtagelsen af en upositioneret position. At tilgå otolittens markeringer kræver hårdt arbejde. Man kan ikke ekstrahere otolitter fra levende laks, og man må således enten dræbe laksen eller indsamle rådnende lig fra nyligt afdøde laks. Derefter må man skære laksens hoved af og rode rundt efter otolitterne, enten med fingrene eller med pincet. Otolitterne sendes derefter til et laboratorie, hvor de lægges på plader og snittes i tynde skiver. Analysen af otolitter er således tydeligvis kropslig - otolitterne skal udvindes med håndkraft - og beror derfor ikke bare på en 
objektiv og distanceret videnskabelig praksis. Når jeg her sammenligner arbejdet med at analysere otolitter og fiskeskæl med arkivarbejde, er det til dels for at understrege, hvordan begge dele også er kropsligt arbejde og handler om at drage konklusioner på baggrund af sit materiale, dels otolitternes altid mangelfulde beskaffenhed. Som det også er tilfældet med traditionel arkivforskning, er analysen af otolitter også altid ufuldkommen: Hvor det materiale, man kan finde i koloniale arkiver, er skævvredet mod det bureaukratiske, fortæller otolitten uforholdsmæssigt meget om fiskens stofskifte, som er ganske vigtigt, men som dog ikke dækker hele fiskens relationelle tilværelse. Ydermere afhænger udfaldet af den pågældende analyse af otolitter også af mange andre forhold: finansieringsforhold, tilgængelige teknologier, disciplinære konventioner og de former for ekspertise, som indgår i selve analysen. Analysen af otolitter producerer således ujævne og delvise rekonstruktioner af fiskens livshistorier og sociale forhold. Man kan med andre ord sige, at otolitter både taler og sættes i tale, men alligevel er meget fortsat usagt.

Hvis vi vil forpligte os til at skabe en robust flerartsantropologi, og hvis vi ønsker at lære mere om, hvordan laks ser landskaber, må vi ikke på forhånd udelukke nogen værktøjer. Analysen af otolitter og lignende kan bestemt benyttes til at styrke fejlagtige vestlige og naturvidenskabelige påstande om universalisme. Men de kan bestemt også gøre andet. Ved at undersøge otolitter finder jeg ikke fakta om enkelte laks og deres verdener: Gennem de utrolige variationer i otolittens markeringer opdager jeg laksens mangfoldighed. Det er dog ikke den samme slags mangfoldighed, som jeg så før, da jeg brugte interviews og deltagerobservation til at udforske, hvordan mennesker konstituerer laks. I stedet er det en slags mangfoldighed, som nok er forbundet med og forankret i de menneskelige måder at konstituere og gøre sig bekendt med laks på - en mangfoldighed, som er forankret i komplekse og dynamiske flerartslige forhold - men hvor menneskelig praksis ikke nødvendigvis spiller en dominerende rolle. Gennem deres otolitter får man øje for, at laks ikke kun gøres i praksisser, men selv praktiserer og gør. De har deres egne mangfoldige måder at se og konstituere akvatiske landskaber på, herunder floder, flodbredder, æstuarier og have. Og disse måder er ofte sammenflettet med mennesker, men ikke indkapslet af dem.

Hvis vi skal gøre os i stand til bedre at bebo en verden, som på mange måder har taget skade af menneskets tilstedeværelse, må vi begynde med at bemærke og beskrive de mangfoldige flerartslige forhold, der udfolder sig i den. At kunne fortælle historier af den slags kræver, at antropologer lærer mere om andre arter. Vores disciplin har brugt årtier på at finpudse metoder til at studere menneskelige sociale relationer, og nu kræver den politiske, etiske og miljømæssige situation, at vi fortæller mere omfattende historier, ikke om kun om os selv, men også om 
os selv i forhold til ikke-menneskelige socialiteter. Til at udføre arbejdet med at skabe disse historier om flerartslig mangfoldighed har vi brug for George og andre forskere, ikke som genstande for vores undersøgelser, men som samarbejdspartnere i vores forsøg på at lære om ikke-menneskelige verdener.

Hvis antropologi skal kunne omstille sig til sådan en verden, kræver det også, at vi omlægger vores metodologi. Det kræver med andre ord, at vi konfronterer og bearbejder de menneskecentrerede metoder, som begrænser vores evne til at lære om ikke-menneskeligt liv og ikke-menneskelige historier. Som samfundsvidenskabelige forskere er vores praksis og vores forpligtelser forbundet med særegne faghistorier, som gør det udfordrende, men så afgjort ikke umuligt at tackle de spørgsmål og udfordringer, som forskningen inden for flerartsantropologi medfører. Det, vi har brug for, er ikke en afvisning af vores allerede eksisterende samfundsvidenskabelige metoder, som er afgørende for at forstå menneskelig praksis, men snarere en styrkelse af rækkevidden af vores opmærksomhed, så vi bedre kan forstå de ikke-mennesker, der også er en del af verden. I lyset af sådanne behov er den observationspraksis, vi finder i analysen af eksempelvis fiskeskæl- og otolitter - analyser, der giver indblik i, hvordan sociale historier manifesterer sig fysisk - vigtige at tage i betragtning. Denne artikel argumenterer derfor for, at vi bør udvide vores metodiske repertoire - en ,medtilblivelse" blandt nye praksisser, som inkluderer de teknikker og redskaber, der typisk betragtes som naturvidenskabelige.

\section{Tak}

Udkast til denne artikel blev præsenteret på American Anthropological Associations konference i 2012 og i 2013 på den årlige konference på Manchester Universitets og Open Universitys Center for Research on Socio-Cultural Change (CRESC) og i 2014 på NOW-projektets Collaborative Moments' workshop i København. Konstruktiv feedback er blevet givet af Zac Caple, Pierre Du Plessis, Elaine Gan, Casper Bruun Jensen, Marianne Lien, Carol Stack og Anna Tsing. Jeg vil også takke Rachel Johnson og George Whitman for deres materielle og intellektuelle bidrag. Forskningen er støttet af STEPS Institute for Innovation in Environmental Research ved University of California, Santa Cruz, og Advanced Gradiate Fellowship ved Pacific Rim Research Program, University of California. Artiklen blev revideret under et skriveophold finansieret af Contemporary Ethnography-program ved Aarhus Universitet.

Oversat af Jannik Friberg Lindegaard 


\section{Noter}

1. Denne litteratur er mangfoldig og spænder fra arbejde med indfødt viden (Cruikshank 2005) til politisk økologi (Goldman et al. 2010) og dyreforsøg (Grasseni 2004). I forhold til laks har Lien og Law vist, hvordan samfundsvidenskabelige metoder såsom deltagerobservation tillader os at forstå, hvordan forskellige laks konstitueres i forhold til forskellige menneskelige praksisser (se Law \& Lien 2013; Lien \& Law 2011).

2. Selv om Jensen og Morita (2017) fokuserer på en bestemt genre af flerartsantropologi, er der genklang med andre antropologiske dialoger, især studier fokuseret på at ,tænke gennem ting“ (Henare et al. 2007) og på „ny materialitet“ (Bennett 2010). Nærværende artikel har interessante ligheder med Holbraad (2011), der har opfordret til at finde nye undersøgelsesmetoder, der går ud over ,folks engagement med ting“ (op.cit.16) for i stedet at undersøge, hvordan ting „taler" gennem deres »materielle egenskaber“" (op.cit.10; se også Holbraad 2013).

3. I samstemmighed med aktør-netværksteori (Callon 1986; Latour 2005) har antropologer i flerartsantropologi understreget, at ,agens“ ikke er en ting, der er eksklusiv for menneskeheden.

4. Tilgange i flerartsantropologi, der bruger STS-argumenter om mangfoldighed som et udgangspunkt (se fx Mol 2002), mangler ofte og utilsigtet de livlige ikke-menneskelige praksisser.

5. Primatologi har haft usædvanligt stærke ikke-vestlige (dvs. Kyoto-skole), feministiske og tværfaglige (dvs. etnoprimatologiske) grene, og mange af forskerne herunder deltager derfor aktivt i politiske og epistemologiske debatter. Disciplinen giver derfor relativt gode betingelser for tværfaglige eksperimenter (Fuentes 2012).

6. Tænk eksempelvis på, hvordan udtryk som „den flerartslige drejning“ og ,menneske-dyrrelationer" ofte ses som løse synonymer for flerartsantropologi.

7. Forskere i flerartsantropologi har også deltaget i samarbejde med biokunstnere, som led $\mathrm{i}$ deres metodologiske eksperimenter (Hodgetts \& Lorimer 2014:5; Johnston \& Kirksey 2014). Jeg formoder, at populariteten af biokunst i flerartsantropologi er knyttet til det noget akavede forhold mellem antropologi og naturvidenskab. Men kunst ser ud til at mægle mellem videnskaberne ved at åbne nye rum for dialog.

8. Et eksempel, som Hodgetts og Lorimer (2014) tilbyder, er olfaktorisk kommunikation blandt medlemmer af væselfamilien.

9. Litteraturen om laks er stor og strækker sig tilbage til 1980'erne. For eksempler på hvad litteraturen fortæller om laksens livshistorier, se Barnett-Johnson et al. (2008), Kennedy et al. (2002), Lind-Null et al. (2008) og Weber et al. (2002).

10. „Videnskabernes krig“ er et udtryk eller et fænomen, der henviser til videnskabelige konflikter i 1990'erne, hovedsagelig i USA mellem samfundsvidenskab og humanister på den ene side, som advokerede for, at al viden er ,konstrueret“", og naturvidenskaben på den anden side, som hævdede at producere objektiv viden om verden.

11. Candea (2010) tager en lignende tilgang, når han nægter at fordømme videnskabelig „løsrivelse". 


\section{Litteratur}

Allen, Collin \& Marc Bekoff

1997 Species of Mind. The Philosophy and Biology of Cognitive Ethology. Cambridge, MA: MIT Press.

Barad, Karen

2007 Meeting the Universe Halfway. Quantum Physics and the Entanglement of Matter and Meaning. Durham, NC: Duke University Press.

Barnett-Johnson, Rachel, Thomas E. Pearson, Frank C. Ramos, Churchill B. Grimes \& R. Bruce MacFarlane

2008 Tracking Natal Origins of Salmon Using Isotopes, Otoliths, and Landscape Geology. Limnology and Oceanography 53(4):1633-42. https://doi.org/10.4319/ 1o.2008.53.4.1633.

Bennett, Jane

2010 Vibrant Matter. A Political Ecology of Things. Durham, NC: Duke University Press.

Callon, Michel

1986 Some Elements of a Sociology of Translation. Domestication of the Scallops and the Fishermen of St. Brieuc Bay. In: J. Law (ed.): Power, Action and Belief. A New Sociology of Knowledge? Pp. 196-223. London: Routledge.

Candea, Matei

2010 "I Fell in Love with Carlos the Meerkat“. Engagement and Detachment in HumanAnimal Relations. American Ethnologist 37(2):241-58. https://doi.org/10.1111/ j.1548-1425.2010.01253.x.

Canfield, Michael R. (ed.)

2011 Field Notes on Science and Nature. Cambridge, MA: Harvard University Press.

Clifford, James \& George E. Marcus (eds)

1986 Writing Culture. The Poetics and Politics of Ethnography. Berkeley: University of California Press.

Cruikshank, Julie

2005 Do Glaciers Listen? Local Knowledge, Colonial Encounters, and Social Imagination. Seattle: University of Washington Press.

Despret, Vinciane

2004 The Body We Care For. Figures of Anthropo-Zoo-Genesis. Body \& Society 10(23):111-34. https://doi.org/10.1177/1357034X04042938.

Evans-Pritchard, E.E.

1940 The Nuer. A Description of the Modes of Livelihood and Political Institutions of a Nilotic People. Oxford: Clarendon Press.

Fausto-Sterling, Anne

1992 Myths of Gender. Biological Theories about Women and Men. $2^{\text {nd }}$ ed. New York: BasicBooks.

Fuentes, Agustin

2012 Ethnoprimatology and the Anthropology of the Human-Primate Interface. Annual Review of Anthropology 41:101-17. https://doi.org/10.1146/annurev-anthro092611-145808. 
Goldman, Mara J., Paul Nadasdy \& Matthew D. Turner (eds)

$2010 \quad$ Knowing Nature. Conversations at the Intersection of Political Ecology and Science Studies. Chicago: University of Chicago Press.

Grasseni, Cristina

2004 Skilled Vision. An Apprenticeship in Breeding Aesthetics. Social Anthropology 12(1):41-55. DOI: 10.1017/S0964028204000035.

Haraway, Donna

1988 Situated Knowledges. The Science Question in Feminism and the Privilege of Partial Perspective. Feminist Studies 14(3):575-99. https://doi.org/10.2307/ 3178066.

2008 When Species Meet. Minneapolis: University of Minnesota Press.

Harding, Sandra

1986 The Science Question in Feminism. Ithaca, NY: Cornell University Press.

Hearne, Vicki

1987 Adam's Task. Calling Animals by Name. New York: Alfred A. Knopf.

Henare, Amiria, Martin Holbraad \& Sari Wastell (eds)

2007 Thinking Through Things. Theorising Artefacts Ethnographically. London: Routledge.

Herman, Steven

1980 The Naturalist's Field Journal. A Manual of Instruction Based on a System Established by Joseph Grinnell. Vermillion, SD: Buteo Books.

Hodgetts, Timothy \& Jamie Lorimer

2014 Methodologies for Animals' Geographies. Cultures, Communication and Genomics. Cultural Geographies 22(2):285-95. https://doi.org/10.1177/ 1474474014525114.

Holbraad, Martin

2011 "Can the Thing Speak?" Open Anthropology Cooperative Press, Working Papers Series No. 7. http://openanthcoop.net/press/http:/openanthcoop.net/press/wpcontent/uploads/2011/01/Holbraad-Can-the-Thing-Speak2.pdf. Læst 6.3.2017.

2013 Things as Concepts. Anthropology and Pragmatology. In: G. Pereira (ed.): Savage Objects. Pp. 17-30. Lissabon: Imprensa Nacional Casa da Moeda.

Ingold, Tim

2011 Being Alive. Essays on Movement, Knowledge and Description. London:

Routledge.

Jensen, Casper \& Atsuro Morita

2017 Introduction. Minor Traditions, Shizen Equivocations, and Sophisticated

Conjunctions. Social Analysis 61(2):1-14.

Johnston, Marnia \& S. Eben Kirksey

2014 Multispecies Salon. http://www.multispecies-salon.org. Læst 6.3.2017.

Keller, Evelyn F.

1982 Feminism and Science. Signs 7(3):589-95.

Kennedy, Brian P., Andrea Klaue, Joel D., Blum, Carol L. Folt \& Keith H. Nislow

2002 Reconstructing the Lives of Fish Using Sr Isotopes in Otoliths. Canadian Journal of Fisheries and Aquatic Sciences 59:925-29. https://doi.org/10.1139/f02-070. 
Kirksey, Eben \& Stefan Helmreich

2010 The Emergence of Multispecies Ethnography. Cultural Anthropology 25(4):545-

76. https://doi.org/10.1111/j.1548-1360.2010.01069.x.

Latour, Bruno

2004 Politics of Nature. How to Bring the Sciences into Democracy. Trans. Catherine Porter. Cambridge, MA: Harvard University Press.

2005 Reassembling the Social. An Introduction to Actor-Network-Theory. New York: Oxford University Press.

Law, John \& Marianne E. Lien

2013 Slippery. Field Notes in Empirical Ontology. Social Studies of Science 43(3):36378. https://doi.org/10.1177/0306312712456947.

Lien, Marianne E. \& John Law

2011 "Emergent Aliens". On Salmon, Nature, and Their Enactment. Ethnos 76(1):65-87. https://doi.org/10.1080/00141844.2010.549946.

Lind-Null, Angie, Kim Larsen \& Reg Reisenbichler

$2008 \quad$ Characterization of Estuary Use by Nisqually Hatchery Chinook Based on Otolith Analysis. US Geological Survey Open-File Report 2008-1102. https: //pubs.usgs.gov/of/2008/1102/.

Longino, Helen E.

1990 Science as Social Knowledge. Values and Objectivity in Scientific Inquiry. Princeton, NJ: Princeton University Press.

Malinowski, Bronislaw

1935 Coral Gardens and Their Magic. London: Routledge.

Mol, Annemarie

2002 The Body Multiple. Ontology in Medical Practice. Durham, NC: Duke University Press.

Popper, Arthur N., John Ramcharitar \& Steven E. Campana

2005 Why Otoliths? Insights from Inner Ear Physiology and Fisheries Biology. Marine and Freshwater Research 56:497-504. https://doi.org/10.1071/MF04267.

Raffles, Hugh

2010 Insectopedia. New York: Vintage Books.

Rappaport, Roy A.

1968 Pigs for the Ancestors. Ritual in the Ecology of a New Guinea People. New Haven, CT: Yale University Press.

Smuts, Barbara

2001 Encounters with Animal Minds. Journal of Consciousness Studies 8(5-7):293-309.

Strum, Shirley C. \& Linda M. Fedigan (eds)

2000 Primate Encounters. Models of Science, Gender, and Society. Chicago: University of Chicago Press.

Tanner, Nancy \& Adrienne Zihlman

1976 Women in Evolution. Part I: Innovation and Selection in Human Origins. Signs 1(3):585-608. https://doi.org/10.1086/493245. 
Tsing, Anna

$2012 \quad$ Unruly Edges. Mushrooms as Companion Species. Environmental Humanities 1(1):141-54. https://doi.org/10.1215/22011919-3610012.

2014 More-than-Human Sociality. A Call for Critical Description. In: K. Hastrup (ed.): Anthropology and Nature. Pp. 27-42. New York: Routledge.

Viveiros de Castro, Eduardo

2004 Perspectival Anthropology and the Method of Controlled Equivocation. Tipití 2(1):3-22. ISSN 2572-3626 (online) Available at: http://digitalcommons.trinity.edu /tipiti/vol2/iss1/1.

Weber, Peter K., Ian D. Hutcheon, Keven D. McKeegan \& B. Lynn Ingram 2002 Otolith Sulfur Isotope Method to Reconstruct Salmon (Oncorhynchus tshawytscha) Life History. Canadian Journal of Fisheries and Aquatic Sciences 59(4):587-91. https://doi.org/10.1139/f02-038. 